\title{
Coding of Spatial Position in the Superior Sulcus of the Macaque
}

C.I. Baker, C. Keizers, T. Jellema, B. Wicker and D.I. Perrett

\section{(2) OpenEdition}

12 Journals

Electronic version

URL: http://journals.openedition.org/cpl/108

DOI: $10.4000 / \mathrm{cpl} .108$

ISSN: $1379-6100$

Publisher

Centre PsyCLÉ

Printed version

Date of publication: 1 April 2000

Electronic reference

C.I. Baker, C. Keizers, T. Jellema, B. Wicker and D.I. Perrett, « Coding of Spatial Position in the Superior Sulcus of the Macaque », Current psychology letters [Online], 2000/1, 1| 2000, Online since 04 September 2003, connection on 08 September 2020. URL : http://journals.openedition.org/cpl/108 ; DOI : https://doi.org/10.4000/cpl.108

This text was automatically generated on 8 September 2020

(c) All rights reserved 


\title{
Coding of Spatial Position in the Superior Sulcus of the Macaque
}

\author{
C.I. Baker, C. Keizers, T. Jellema, B. Wicker and D.I. Perrett
}

